UDK $577.1: 61$

ISSN 1452-8258

J Med Biochem 37: 313-319, 2018

\title{
ASSESSMENT OF SERUM LEVELS OF THE ADIPOCYTOKINE CHEMERIN IN COLORECTAL CANCER PATIENTS
}

\author{
UTVRĐIVANJE NIVOA ADIPOCITOKINA KEMERINA U SERUMU \\ KOD OBOLELIH OD KOLOREKTALNOG KARCINOMA \\ Manal M. Alkady, Phebe L. Abdel-Messeih, Neveen M. Nosseir \\ Radiation Health Research Department, National Center for Radiation Research and Technology, \\ Atomic Energy Authority, Cairo, Egypt
}

\begin{abstract}
Summary
Background: Colorectal cancer (CRC) is one of the most common cancers worldwide. The tumor microenvironment is very important for determining cancer cell growth and spreading. Chemerin, a newly identified adipokine secreted by adipose tissue, is known to be associated with obesity, metabolic syndrome, and insulin resistance. The present study was carried out to investigate the association between serum levels of chemerin and colorectal cancer.

Methods: Thirty-two patients with colorectal cancer aged $57.6 \pm 6.5$ years, and twenty age, sex and BMI matched healthy controls were included in the study. Serum chemerin levels were determined using enzyme linked immunosorbent assay. C-reactive protein (CRP) levels were determined using a turbidimetric immunoassay. Carcinoembryonic antigen (CEA) and carbohydrate antigen (CA 19-9) were measured by radioimmunoassay.

Results: Chemerin levels were found to be significantly higher in patients relative to the controls $(P<0.001)$ and gradually increased with the TNM tumor stage progression. The mean CRP, CEA and CA 19-9 levels were also significantly higher in patients $(P<0.001)$. There was a significant correlation between the serum levels of chemerin and the other measured parameters in CRC patients. The area under receiver operating characteristic curve (ROC) for serum chemerin was 1 at a cut-off value $\geq 161.5$ with $100 \%$ sensitivity and $100 \%$ specificity.
\end{abstract}

\begin{abstract}
Kratak sadržaj
Uvod: Kolorektalni karcinom (KRK) jedan je od najčešćih oblika karcinoma širom sveta. Mikrookolina tumora veoma je važna za procenu rasta i širenja ćelija kancera. Kemerin je nedavno identifikovan adipokin koji se izlučuje iz adipoznog tkiva i utvrđeno je da je povezan sa gojaznošću, metaboličkim sindromom i insulinskom rezistencijom. Ova studija sprovedena je kako bi se ispitala povezanost između nivoa kemerina u serumu i kolorektalnog karcinoma.

Metode: U studiju je uključeno 32 pacijenta sa kolorektalnim karcinomom starosti 57,6 6 6,5 godina i 20 zdravih kontrolnih osoba odgovarajuće starosti, pola i indeksa telesne mase (ITM). Nivoi kemerina u serumu određeni su pomoću ELISA testa. Nivoi C-reaktivnog proteina (CRP) određeni su pomoću turbidimetrijskog imunoodređivanja. Karcinoembrioni antigen (CEA) i ugljenohidratni antigen (CA19-9) mereni su radioimunoodređivanjem.

Rezultati: Nivoi kemerina bili su značajno viši kod obolelih u odnosu na kontrolne osobe $(\mathrm{P}<0,01)$ i postepeno su rasli zajedno sa stepenima tumorske skale TNM. Srednji nivoi CRP, CEA i CA 19-9 bili su takođe značajno viši kod obolelih $(P<0,001)$. Pronađena je značajna korelacija između nivoa kemerina u serumu i ostalih merenih parametara kod obolelih od KRK-a. Površina ispod ROC krive za kemerin u serumu bila je 1 pri cutoff vrednosti $\geq 161,5$, uz osetljivost od $100 \%$ i specifičnost od $100 \%$.
\end{abstract}

\footnotetext{
Address for correspondence:

Dr. Manal M Alkady, Department of Radiation Health Research, National Center for Radiation Research and Technology, Atomic Energy Authority, P.O. Box 29, Nasr City, Cairo, Egypt e-mail: mankady@msn.com
}

List of abbreviations: Carbohydrate antigen (CA 19-9); carcinoembryonic antigen (CEA); C-reactive protein (CRP); tumor necrosis factor alpha (TNF- $\alpha$ ); vascular cell adhesion molecule-1 (VCAM-1); MMP-7, matrix metalloproteinase-7; ERK1/2, extracellular signal-regulated kinase. 
Conclusions: The observed results suggest that chemerin may have a potential role in the pathogenesis and progression of colorectal malignancy and may be a good biomarker of colorectal cancer and stage progression.

Keywords: colorectal cancer, chemerin, C-reactive protein, carcinoembryonic antigen

\section{Introduction}

Colorectal cancer (CRC) is the third most commonly diagnosed malignancy and the fourth leading cause of cancer death in the world, accounting for about 1.4 million new cases and almost 700000 deaths in 2012 (1). In Egypt, GLOBOCAN 2012 showed that colorectal cancer is considered the 8th cancer after breast, liver, non-Hodgkin lymphoma, brain, ovary, leukemia and bladder cancer with an incidence rate accounting for $4 \%$ and $3.5 \%$ for men and women respectively.

The association between obesity and human malignancies including colorectal cancer (CRC) has been increasingly recognized, but the underlying biological mechanisms are not fully understood. Chronic inflammation, insulin resistance and adipocytokines are contributing factors (2-4).

Adipokines are polypeptide cytokines produced by white adipose tissue, acting not only as local paracrine signaling cytokines, but also at distant levels, through secretion in the circulation (5). In obesity, the hypertrophic expansion of adipose tissue induces local hypoxia, inflammatory activation and reactive angiogenesis, changes which favor tumorigenesis (6). More than 15 adipokines have been reported to be associated with cancers (7). While the circulating levels of proinflammatory adipokines, such as leptin, IL-6 and tumor necrosis factor alpha (TNF- $\alpha$ ), are increased in cancers, some others such as adiponectin are protective against tumorigenesis and its serum levels are usually decreased in the patients with cancer (8).

Chemerin is a novel adipokine, which plays an important role in adipogenesis and chemotaxis of the innate immune system (9). Chemerin and its major receptor, CMKLR1, are expressed in white adipose tissue, and circulating levels of this adipokine are elevated in obesity and metabolic syndrome (10). It may link obesity and inflammation since chemerin is a proinflammatory cytokine that recruits and activates immune cells and contributes to inflammation by promoting macrophage adhesion to vascular cell adhesion molecule-1 (VCAM-1) and fibronectin (11). The association of chemerin and cancer is not yet fully understood. Chemerin promotes angiogenesis via inducing matrix metalloproteinase secretion and activity. Therefore, it is thought that high levels of chemerin may have an initiating role in a further process; carcinogenesis, then metastasis (12). Otherwise, che-
Zaključak: Uočeni rezultati sugerišu da kemerin ima potencijalnu ulogu u patogenezi i progresiji kolorektalnog maligniteta i da bi mogao biti dobar biomarker za kolorektalni karcinom i stepen progresije.

Ključne reči: kolorektalni karcinom, kemerin, C-reaktivni protein, karcinoembrioni antigen

merin was demonstrated to recruit natural killer cells which are suggested to play a great role in antitumor defense (13). So, in this study we aimed to evaluate the serum levels of chemerin in colorectal cancer patients to understand the possible role of adipocytokines in relation to CRC development and progression.

\section{Subjects and Methods}

This is a case-control study including thirty-two patients attending the gastrointestinal endoscopy unit of the tropical medicine department, Kasr El Aini hospital, Faculty of Medicine, Cairo University. All had been diagnosed with CRC after colonoscopy, aged $57.6 \pm 6.5$ years. Exclusion criteria: no curative medication for CRC; no previous history of malignancy or colorectal operations; no diagnosis of familial adenomatous polyposis or acromegaly; no diagnosis of any inflammatory bowel disease, including ulcerative colitis and Crohn's disease; patients with diabetes mellitus, chronic liver and kidney diseases were excluded. Twenty healthy subjects of comparable age and sex and $\mathrm{BMI}$ served as a control group.

All procedures were performed according to the ethical standards of the institutional and national research committee given in the Declaration of Helsinki 1964, as revised in 2013. A written informed consent of participation in the study was taken from all participants. This study was approved by the Committee of Ethics and Research of the university hospital.

Fasting blood samples were collected from all subjects in blank vacutainers, left to clot, centrifuged and the sera were separated and stored at $-20^{\circ}$ till assay date.

Biochemical analysis:

- Fasting blood sugar was measured by glucose oxidase method (Beckman Glucose Analyzer, Fullerton, CA, USA)

- Serum cholesterol and TG were measured using an automated system Hitachi 912 analyzer using an enzymatic method. Serum HDL and LDL were measured using an automated system Cobas C 311/501 analyzer using an enzymatic method.

- Chemerin was measured by a competitive immunoenzymatic method with the commer- 
cially available ELISA kits, human chemerin quantikine ELISA kit, supplied by R\&D Systems, Inc (14).

- The CRP levels were determined using a turbidimetric immunoassay (Roche Modular Analytics P800; Roche Diagnostics, Indianapolis, IN).

- CEA and CA 19-9 were performed using commercial radioimmunoassay kits (CIS Bio International, France).

\section{Statistical analysis}

The results were expressed as mean \pm standard deviation. The statistical difference between groups was analyzed using Student's $t$ test. Pearson's correlation analysis was performed to determine the relationships between variables. The results were considered significant at $P<0.05$. ROC curves were constructed to assess reliability of the new marker in detection of CRC lesions. Sensitivity and specificity were calculated in relation to the best cut-off value obtained from the curve. The statistical calculations were done using Statistical Package for the Social Sciences version 15 software, while the presentations were performed using Microsoft Excel 2007.

\section{Results}

Table I shows the anthropometric measurements, biochemical parameters, serum adipocytokine chemerin, CRP, CEA and CA 19-9 levels in the group of patients with CRC (32 subjects) compared with the control group (20 subjects). No significant differences have been observed in age, gender, BMI, FBS, cholesterol, triglycerides, $\mathrm{HDL}$ and $\mathrm{LDL}$ means among the patients with CRC and controls. Serum chemerin levels were significantly higher $(p<0.001)$ in CRC patients $(377.4 \pm 80.3 \mathrm{ng} / \mathrm{mL})$ when compared with controls $(87.8 \pm 22.01 \mathrm{ng} / \mathrm{mL})$. Serum CRP levels were significantly higher $(p<0.001)$ in CRC patients (218.48 $\pm 64.8 \mathrm{nmol} / \mathrm{L})$ compared with the control group (49.05 $\pm 34.3 \mathrm{nmol} / \mathrm{L})$. CEA levels were significantly higher $(p<0.001)$ in CRC $(15.59 \pm 5.63 \mathrm{ng} / \mathrm{mL})$ when compared with controls (1.77 $\pm 0.47 \mathrm{ng} / \mathrm{mL})$ and CA 19-9 levels were significantly higher $(p<0.001)$ in CRC patients (130.39 $\pm 42.7 \mathrm{U} / \mathrm{mL}$ ) compared with the control group (20.58 $\pm 7.6 \mathrm{U} / \mathrm{mL})$. Table // illustrates the correlation between the different studied parameters in patients with CRC. There was a significant positive correlation between serum chemerin levels and CRP $(r=0.98, p<0.001)$. A significant positive correlation was found between chemerin and CEA levels in patients with CRC $(r=0.95, P<0.001)$. There was a significant positive correlation between serum chemerin levels and CA 19-9 in CRC patients $(r=0.97, p<0.001)$. Figure 2 illustrates serum chemerin levels at different TNM stages of CRC.

Serum chemerin levels were significantly higher in advanced stage patients than those of early stage patients $(p<0.05)$ [stage I $(275.2 \pm 58.7 \mathrm{ng} / \mathrm{mL})$,

Table II Correlation between chemerin and other studied parameters in the group of CRC patients.

\begin{tabular}{|l|c|c|}
\hline & $r$ & $p$-value \\
\hline Chemerin and CRP & 0.98 & $<0.001$ \\
\hline Chemerin and CEA & 0.95 & $<0.001$ \\
\hline Chemerin and CA 19-9 & 0.97 & $<0.001$ \\
\hline
\end{tabular}

Table I Demographic, anthropometric and metabolic parameters, serum chemerin, CRP, CEA and CA 19-9 in CRC patients and controls (Mean \pm SD).

\begin{tabular}{|l|c|c|c|}
\hline & $\begin{array}{c}\text { Controls } \\
\text { No=20 }\end{array}$ & $\begin{array}{c}\text { CRC patients } \\
\text { No=32 }\end{array}$ & P-value \\
\hline Age (years) & $58.4 \pm 7.2$ & $57.6 \pm 6.5$ & NS \\
\hline Gender (male/female) & $14 / 6$ & $22 / 10$ & NS \\
\hline BMI $\left(\mathrm{kg} / \mathrm{m}^{2}\right.$ ) & $26.7 \pm 5.3$ & $25.8 \pm 4.2$ & NS \\
\hline Fasting glucose (mmol/L) & $4.52 \pm 0.36$ & $4.49 \pm 0.43$ & NS \\
\hline Cholesterol (mmol/L) & $4.097 \pm 0.68$ & $4.048 \pm 0.72$ & NS \\
\hline Triglycerides $(\mathrm{mmol} / \mathrm{L})$ & $2.12 \pm 0.55$ & $2.08 \pm 0.68$ & $\mathrm{NS}$ \\
\hline HDL $(\mathrm{mmol} / \mathrm{L})$ & $1.199 \pm 0.13$ & $1.145 \pm 0.14$ & $\mathrm{NS}$ \\
\hline LDL $(\mathrm{mmol} / \mathrm{L})$ & $2.32 \pm 0.63$ & $2.24 \pm 0.72$ & $<0.001$ \\
\hline Chemerin $(\mathrm{ng} / \mathrm{mL})$ & $87.8 \pm 22.01$ & $377.4 \pm 80.3$ & $<0.001$ \\
\hline CRP $(\mathrm{nmol} / \mathrm{L})$ & $49.05 \pm 34.3$ & $218.48 \pm 64.8$ & $<0.001$ \\
\hline CEA $(\mathrm{ng} / \mathrm{mL})$ & $1.77 \pm 0.47$ & $15.59 \pm 5.63$ & $<0.001$ \\
\hline CA 19-9 (U/mL) & $20.58 \pm 7.6$ & $130.39 \pm 42.7$ & $<$ \\
\hline
\end{tabular}




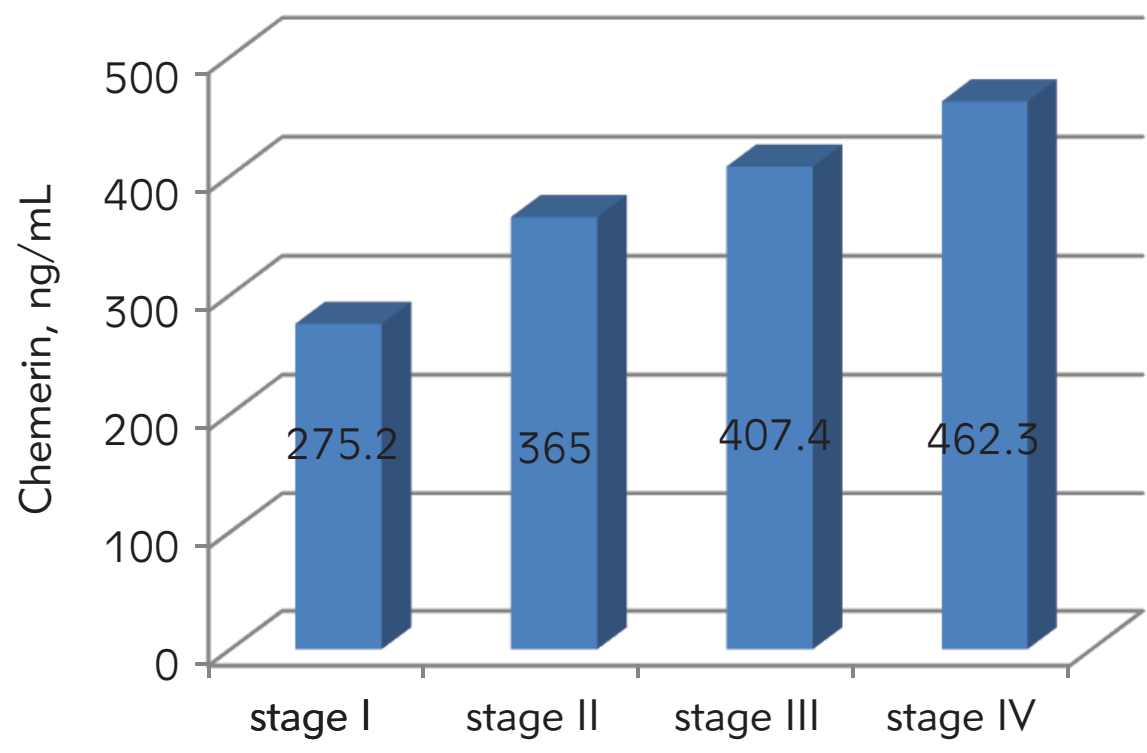

Series 1

Figure 1 Serum chemerin levels of CRC patients in different TNM stages.

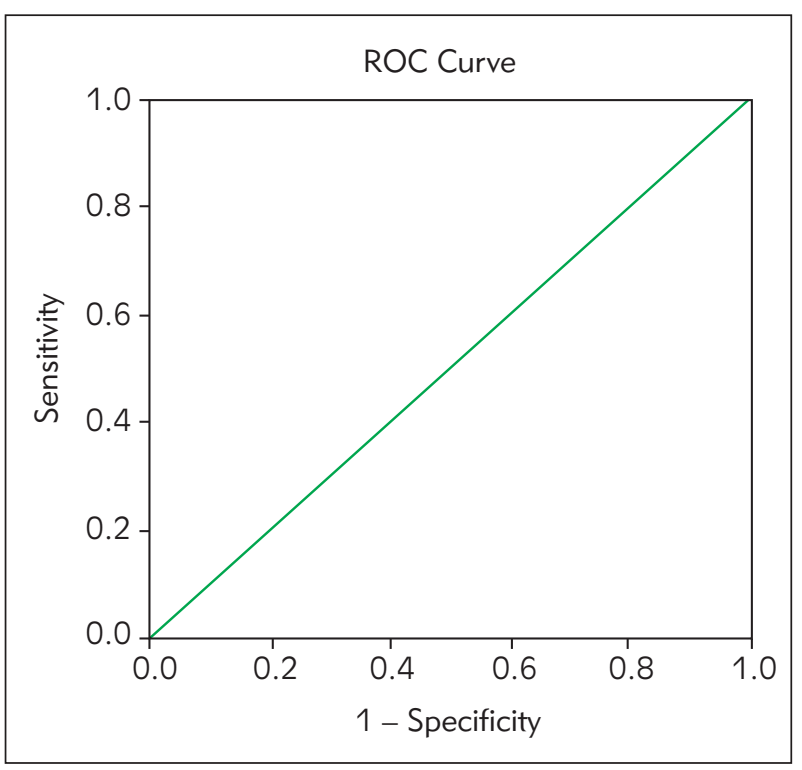

Figure 2 The ROC curve for serum chemerin in differentiating CRC patients and healthy controls. The area under curve (AUC) value of serum chemerin was 1.00 , with $100 \%$ sensitivity, $100 \%$ specificity at a cut-off value of $\geq 161.5$.

stage II $(365 \pm 34.6 \mathrm{ng} / \mathrm{mL})$, stage III $(407.4 \pm 21.8$ $\mathrm{ng} / \mathrm{mL})$, stage IV $(462.3 \pm 45.6 \mathrm{ng} / \mathrm{mL})$.

To assess the performance of serum chemerin as a marker, ROC curves were used to calculate the sensitivity of this marker in separating CRC patients from healthy controls. As shown in Figure 2, an area under the curve (AUC) value for serum chemerin reached 1.0. With a cut-off value of $161.5 \mathrm{ng} / \mathrm{mL}$, serum chemerin has a sensitivity of $100 \%$, a specificity of $100 \%$ and $p<0.0001$. These results indicated that serum chemerin is a valuable biomarker for CRC diagnosis.

\section{Discussion}

The association of colorectal cancer with the alteration of adipokines in blood has not been fully elucidated. Obesity is linked significantly to adipose tissue dysfunction, and obesity-induced inflammation is thought to be an important link between obesity and colorectal cancer (15). Chemerin is a novel member of adipokines that plays important roles in regulating angiogenesis, cell proliferation and migration, inflammation, chemotaxis, glucose, and lipid metabolism (16). Although the dysregulated expression of chemerin in the tumor tissues has been reported, the results are inconsistent. A probable explanation for these inconsistencies is that the expression of chemerin may vary in different types of cancers, which is a common phenomenon in tumor biology (17). In our study, we demonstrated that the serum chemerin level was higher in the CRC patients than in the control subjects. The same results were observed by Erdogan et al. (18) who reported that higher levels of circulating chemerin, CRP, fibrinogen levels, and ESR values are associated with an increased risk of developing CRC. They reported that inflammation is 
an important risk factor in carcinogenesis, and chemerin constitutes an interesting candidate as an inflammatory marker.

A great number of studies have demonstrated that adipokines play important roles in tumor angiogenesis, invasion, differentiation, and progression. Wang et al. (19) determined the serum levels of chemerin in gastric cancer patients and healthy subjects to investigate the biological effect of chemerin on gastric cancer cells. Serum level of chemerin was significantly higher in gastric cancer patients than healthy subjects $(P<0.01)$. The elevation of serum chemerin level was associated with advanced clinical stages of gastric cancer. They also reported that chemerin increased invasiveness of gastric cancer cells and induced phosphorylation of p38 and ERK1/2 MAPKs and upregulated VEGF, MMP-7 and IL-6. Inhibition of ERK1/2 phosphorylation abolished the upregulation of VEGF, MMP-7 and IL-6 and the proinvasive effect of chemerin. In another study, plasma chemerin levels were found to be significantly elevated in patients with gastric cancer than in healthy controls and were associated with long-term poor prognosis and survival of gastric cancer patients indicating that chemerin might be a prognostic biomarker in gastric cancer (20). A study by Xu et al. (21) showed that serum chemerin levels were significantly elevated in non-small cell lung cancer (NSCLC) patients compared with the controls, and there was a strong association between high serum chemerin levels and TNM stages, lymph node metastasis, and distant metastasis. Furthermore, NSCLC patients with higher serum chemerin levels had poorer prognosis, suggesting that serum chemerin may be a useful clinical biomarker in the diagnosis, progression and prognostic evaluation of NSCLC. In our study, we obtained similar results, in that chemerin levels are significantly higher in advanced TNM stages of CRC.

Many other studies demonstrated overexpression of chemerin in oral squamous cell carcinoma (22), and oesophageal squamous cancer (23). On the other hand, chemerin expressions are downregulated in melanoma, and hepatocellular carcinoma $(24,25)$.

Lin et al. (26) found that HCC patients had much lower serum chemerin levels compared with healthy subjects. Furthermore, chemerin expression at mRNA and protein levels was significantly lower in tumor than paratumor tissues from HCC patients. Their study revealed a novel tumor-inhibitory role of chemerin in HCC by suppressing tumor-associated inflammation. The antitumor immune response is regulated by numerous factors, including cytokines produced by the tumor-infiltrating lymphocytes and activated immune cells (i.e., macrophages, dendritic cells, and lymphocytes). The locally and systemically produced mixture of cytokines plays a pivotal role in the induction of host immune response, which can either block or facilitate tumor growth (27).
Cytokine regulation of human CRC is not clearly understood. The systemic and local cytokine environment may modulate the immunogenicity of colorectal cancer cells and affect antitumor immune function of tumor-infiltrating lymphocytes. Focusing on individual cytokines has generated evidence that proinflammatory cytokines and antiinflammatory cytokines may have a complex role in gastrointestinal carcinogenesis (28).

Today, inflammation is known to be a hallmark of cancer. Chronic inflammation is associated with an increase in cancer risk (29). If the cell proliferation occurs in an environment which is rich in growth factors, inflammatory cells, DNA damage-promoting agents, and activated stroma, it increases neoplastic risk (30). The C-reactive protein predicts reduced survival in gastrointestinal cancer patients and is a wellrecognized marker of inflammation (31). Increased CRP concentration has been shown to be a strong independent prognostic factor of CRC (32). In our study, the serum CRP level was significantly higher in CRC patients than control subjects, and it was higher with the advancing TNM classification. There was a positive significant correlation between chemerin and CRP. Our findings are in agreement with the results of several previous studies $(33,21)$. Erdogan et al. (21) reported that chemerin constitutes an interesting candidate as an inflammatory marker.

An ideal diagnostic biomarker should have high disease sensitivity and specificity and provide a cut off value with minimal overlap between normal and disease states. In view of that, serum chemerin in this study was revealed as an excellent diagnostic biomarker in discriminating CRC patients from healthy controls.

In the current study, the area under curve (AUC) value of serum chemerin was 1.00 , with $100 \%$ sensitivity and specificity, and diagnostic accuracy at a cutoff value of $\geq 161.5$.

Xu et al. (24) assessed the performance of serum chemerin as a marker in separating NSCLC patients from healthy controls. They reported that at a cut-off value of $1500 \mathrm{pg} / \mathrm{mL}$, serum chemerin has a sensitivity of $62.4 \%$, and a specificity of $67.5 \%$. The combined diagnostic value of chemerin and CEA in NSCLC was further detected. The results showed that the combined detection of these two indices had a sensitivity of $78.3 \%$ and a specificity of $84.2 \%$. The combination of chemerin and CEA produced better sensitivity and specificity than chemerin and CEA alone. In another study, ROC curve analysis revealed that serum chemerin has $100 \%$ sensitivity and 100\% specificity with an area under the curve (AUC) of 1.00 in detecting early stage oral squamous cell carcinoma (OSCC) at a cut-off value of $307 \mathrm{ng} / \mathrm{mL}$ (34).

In conclusion, our findings suggest that the adipokine chemerin may have a potential role in the development of CRC and may be a novel and promising biomarker of colorectal cancer and stage progression. 


\section{Financial support and sponsorship}

Nil.

\section{Authors' Contributions}

MMA contributed in the conception and design of the work, coordinated and carried out all experiments, performed the statistical analysis, participated in manuscript preparation, revised the draft, approved the final version of the manuscript, and agreed to all aspects of the work. PhLM contributed in the conception of the work, provided assistance for all experi-

\section{References}

1. Ferlay J, Soerjomataram I, Ervik $M$, Dikshit R, Eser $S$, Mathers C, Rebelo M, Parkin DM, Forman D, Bray F. GLOBOCAN 2012 v1.0, Cancer Incidence and Mortality Worldwide: IARC Cancer Base No. 11. Lyon, France: International Agency for Research on Cancer, 2013.

2. Van Kruijsdijk RC, van der Wall E, Visseren FL. Obesity and cancer: the role of dysfunctional adipose tissue. Cancer Epidemiology Biomarkers and Prevention 2009; 18(10): 2569-78.

3. Zhang Y, Song $X$, Wang $X$, Hu J, Jiang L. Silencing of LncRNA HULC enhances chemotherapy induced apoptosis in human gastric cancer. J Med Biochem 2016; 35: 137-43.

4. Llanos AA, Dumitrescu RG, Marian C, Makambi KH, Spear SL, Kallakury BV, Perry DJ, Convit RJ, Platek ME, Millen AE. Adipokines in plasma and breast tissues: Associations with breast cancer risk factors. Cancer Epidemiology Biomarkers and Prevention 2012; 21(10): 1745-55.

5. Raucci R, Rusolo F, Sharma A, Colonna G, Castello G, Costantini S. Functional and structural features of adipokine family. Cytokine 2013; 61: 1-14.

6. Tulubas F, Mete R, Oznur M, Topcu B. The role of adipocytokines in colon cancer and adenomas. J Med Biochem 2014; 33: 136-42.

7. Arner E, Forrest AR, Ehrlund A, Mejhert N, Itoh M, Kawaji $H$, Lassmann T, Laurencikiene J, Rydén M, Arner P. Ceruloplasmin is a novel adipokine which is overexpressed in adipose tissue of obese subjects and in obesity-associated cancer cells. PLoS ONE 2014; 27, 9(3): e80274.

8. Park J, Morley TS, Kim M, Clegg DJ, Scherer PE. Obesity and cancer mechanisms underlying tumour progression and recurrence. Nature Reviews. Endocrinology 2014; 10: $455-65$

9. Rourke JL, Dranse HJ, Sinal CJ. Towards an integrative approach to understanding the role of chemerin in human health and disease. Obes Rev 2013; 14: 24562.

10. Bozaoglu K, Bolton K, McMillan J, Zimmet P, Jowett J, Collier G, Walder K, Segal D. Chemerin is a novel ments, revised the draft, approved the final version of the manuscript, and agreed to all aspects of the work. NMN contributed in the conception and design of the work, collected samples from patients, prepared the manuscript and revised the draft, approved the final version of the manuscript, and agreed to all aspects of the work.

\section{Conflict of interest statement}

The authors stated that they have no conflicts of interest regarding the publication of this article.

adipokine associated with obesity and metabolic syndrome. Endocrinology 2007; 148: 4687-94.

11. Ouchi N, Parker JL, Lugus JJ, Walsh K. Adipokines in inflammation and metabolic disease. Nat Rev Immunol 2011; 11(2): 85-97.

12. Kaur J, Adya R, Tan BK, Chen J, Randeva HS. Identification of chemerin receptor (ChemR23) in human endothelial cells: chemerin-induced endothelial angiogenesis. Biochem Biophys Res Commun 2010; 391: 1762-8.

13. Skrzeczyńska-Moncznik J, Stefanska A, Zabel BA Kapińska-Mrowiecka M, Butcher EC, Cichy J. Chemerin and the recruitment of NK cells to diseased skin. Acta Biochim Pol 2009; 56: 355-60.

14. Monnier J, Lewen S, O'Hara E, Huang K, Tu H, et al. Expression, regulation, and function of atypical chemerin receptor CCRL2 on endothelial cells. J Immunol 2012; 189: 956-67.

15. Gunter MJ, Hoover DR, Yu H, Wassertheil-Smoller S Rohan TE, Manson JE, Howard BV, Wylie-Rosett J, Anderson GL, Ho GY, Kaplan RC, Li J, Xue X, Harris TG, Burk RD, Strickler HD. Insulin, insulin-like growth factorI, endogenous estradiol, and risk of colorectal cancer in postmenopausal women. Cancer Res 2008; 681(1), 329-37.

16. Booth A, Magnuson A, Fouts J, Foster M. Adipose tissue, obesity and adipokines: role in cancer promotion. Horm Mol Biol Clin Investig 2015; 21(1): 57-74.

17. Oliveira-Ferrer L, Tilki D, Ziegeler G, Hauschild J, Loges $S$, Irmak S, Kilic E, Huland H, Friedrich M, Ergun S. Dual role of carcinoembryonic antigen-related cell adhesion molecule 1 in angiogenesis and invasion of human urinary bladder cancer. Cancer Res 2004; 64: 8932-8.

18. Erdogan S, Yilmaz FM, Yazici O, Yozgat A, Sezer S, Ozdemir N, Uysal S, Purnak T, Sendur MA, Ozaslan E. Inflammation and chemerin in colorectal cancer. Tumour Biol 2016; 37(5): 6337-42.

19. Wang C, Wu WK, Liu X, To KF, Chen GG, Yu J, Ng EK. Increased serum chemerin level promotes cellular invasiveness in gastric cancer: a clinical and experimental study. Peptides 2014; 51: 131-8. 
20. Zhang J, Jin HC, Zhu AK, Ying RC, Wei W, Zhang FJ. Prognostic significance of plasma chemerin levels in patients with gastric cancer. Peptides 2014; 61: 7-11.

21. Xu CH, Yang Y, Wang YC, Yan J, Qian LH. Prognostic significance of serum chemerin levels in patients with nonsmall cell lung cancer. Oncotarget 2017; 8(14): 224839.

22. Wang N, Wang QJ, Feng YY, Shang W, Cai M. Overexpression of chemerin was associated with tumor angiogenesis and poor clinical outcome in squamous cell carcinoma of the oral tongue. Clin Oral Investig 2014; 18: 997-1004.

23. Kumar JD, Kandola S, Tiszlavicz L, Reisz Z, Dockray GJ, Varro A. The role of chemerin and ChemR23 in stimulating the invasion of squamous oesophageal cancer cells. Br J Cancer 2016; 10: 114(10): 1152-9.

24. Pachynski RK, Zabel BA, Kohrt HE, Tejeda NM, Monnier J, Swanson CD, Holzer AK, Gentles AJ, Sperinde GV, Edalati A, Hadeiba HA, Alizadeh AA, Butcher EC. The chemoattractant chemerin suppresses melanoma by recruiting natural killer cell antitumor defenses. J Exp Med 2012; 209(8): 1427-35.

25. Lin W, Chen $Y L$, Jiang L, Chen JK. Reduced expression of chemerin is associated with a poor prognosis and a lowed infiltration of both dendritic cells and natural killer cells in human hepatocellular carcinoma. Clin Lab 2011; 57: 879-85.

26. Lin $Y$, Yang $X$, Liu W, Li B, Yin W, Shi Y, He R. Chemerin has a protective role in hepatocellular carcinoma by inhibiting the expression of IL-6 and GM-CSF and MDSC accumulation. Oncogene 2017; 36: 3599-608; doi:10.1038/onc.2016.516.
27. Dunn GP, Old $\sqcup$, Schreiber RD. The immunobiology of cancer immunosurveillance and immunoediting. Immunity 2004; 21: 137-48.

28. Dalerba P, Maccalli C, Casati C, Castelli C, Parmiani G. Immunology and immunotherapy of colorectal cancer. Crit Rev Oncol Hematol 2003; 46(1): 33-57.

29. Aggarwal BB, Gehlot P. Inflammation and cancer: how friendly is the relationship for cancer patients? Curr Opin Pharmacol 2009; 9: 351-69.

30. Coussens LM, Werb Z. Inflammation and cancer. Nature 2002; 420: 860-7.

31. Cahlin C, Lonnroth C, Arvidsson A, Nordgren S, Lundholm K. Growth associated proteins in tumor cells and stroma related to disease progression of colon cancer accounting for tumor tissue PGE2 content. Int J Oncol 2008; 32(4): 909-18.

32. Tomašević R, Milosavljević $T$, Stojanović $D$, Gluvić $Z$, Dugalić P, Ilić I, Vidaković R. Predictive value of carcinoembryonic and carbohydrate antigen 19-9 related to some clinical, endoscopic and histological colorectal cancer characteristics. J Med Biochem 2016; 35: 324-32.

33. Swede H, Hajduk AM, Sharma J, Rawal S, Rasool H, Vella AT, Tobet RE, Stevens RG. Baseline serum C-reactive protein and death from colorectal cancer in the NHANES III cohort. Int J Cancer 2014; 134: 1862-70.

34. Ghallab NA, Shaker OG. Serum and salivary levels of chemerin and MMP-9 in oral squamous cell carcinoma and oral premalignant lesions. Clin Oral Invest 2017; 21: 937-47. 